right away. The trouble, at Atlanta, is that an employee of the bank issued letters of credit amounting to more than $\$ 2,000$ million to agencies of the government of Iraq without his employers knowing. Iraq is of course the paper victor in the long Gulf War with Iran, and has to replenish its military equipment; the names of the companies in whose favour the letters of credit have been drawn are suggestive of that. But Iraq has also plans to build a longrange missile, and may be buying (or hoping to buy) the necessary components.

So too, of course, does Israel. That the most embattled country in the Middle East should be equipped to defend itself against strategic attack is legitimate enough. But at 1,500 kilometres - the range at which both Iraq and Israel strive - missiles do not make sense as tactical battlefield weapons, because they are insufficiently accurate. Prudent generals will therefore insist that, with missiles of such a range, only nuclear warheads can make sense. They will do so in the process of convincing themselves that deterrence is a way of preventing wars and not of winning battles.

That is where, for the rest of us, the bad news appears. Even generals have to make housekeeping calculations. Would it be better to spend the money on, say, Kalashnikov automatic rifles, or on the means of building and launching 1,500-kilometre missiles and the nuclear warheads to go with them? Hitherto, most generals have acted conservatively, although it is so probable as nearly to be certain that Israel already has a substantial stock of nuclear warheads. Iraq, by contrast, is a long-standing member of the Nuclear Non-Proliferation Treaty (and thus is still rightly indignant that its research reactor should have been illegally attacked by Israel in 1982). Now, with the help of a paper-pusher in Atlanta, it has created the illusion of being a big player. But what if the illusion conceals an identical reality? Ceteris paribus, as the economists say, there will be at least two overt nuclear powers in the Middle East ten years from now.

That should keep most of us from our beds at night. A nuclear Middle East would be the Lebanon, as now, writ large. Nobody, especially not those most concerned, would benefit. But how to avoid the prospect? It would help if there could be a conference on the Middle East, but Mr George Bush seems to prefer staying at home and Mr Mikhail Gorbachev has little choice, so that the mayhem in the occupied territories will continue. The International Atomic Energy Agency, run by a Board of Governors representing the world establishment (which meets next week) might exert its influence, but will not. The best way of avoiding real trouble would be for India and Pakistan - whose present leaders are well-disposed towards each other and the future except when one or the other faces trouble (an election or just fractious opposition) - should make a nuclear-weapons deal. Otherwise, there is a danger that the long-withheld promise of a comprehensive test-ban treaty between the open nuclear powers, the best way forward at Geneva now, will simply be overtaken by events.

\section{Tunnel to nowhere}

The British government's neglect of transport's to Eurotunnel may be a deliberate ploy.

ONCE upon a time, there were inveterate enemies separated from each other by a narrow strip of water called the English Channel, who liked to fight each other at every opportunity, at places with mellifluous names such as Agincourt (the ' $\mathrm{g}$ ' is soft, as in the middle consonant of 'Brezhnev'). But after many battles and with the passage of time, even these considerable warriors became sated with their victories. (Both had a flair for not remembering, or even recording, their defeats.) So one of them went to Rome to sign a treaty to engage in equal and free trade with its neighbours while the other declined the invitation; everybody sighed with relief, believing that their quarrelsomeness would for ever after be directed against quite different enemies.

Sadly, the outcome has been otherwise, but for a curious reason: most people know geography, but hardly anybody understands it. Living on an island is a splendid state of grace if you believe that everybody else would also like to live there - and if you know they cannot make the journey. But if you have reason to believe that other people do not share your fondness for island life, you quickly discover that island life is a recipe for isolation. The fairy story accounts for British vacillations about the European Community over the past forty years.

More recently, there has been an even more curious happening. The British and French governments, each with ten centuries of recorded history at its back, have come to recognize that people could (and did) cross the English Channel on foot not much further back in time (say, 10,000 years ago). Mindful (as UN communiques say) that the English (as they were then called) were seized by the fear, at the height of the Napoleonic Wars, that the French might dig a tunnel and walk beneath the Channel, they agreed to exorcize the nightmare by building a tunnel in the full glare of publicity; they would send television cameramen down the tunnel at every opportunity, and would not pay for it themselves, giving its operators a chance to make money from it instead.

Only then did an odd thing come to light: the English, having agreed that there should be a tunnel free for all to use, neglected to make arrangements for conveying people or their possessions from the end of the tunnel to whichever places they wished to go. The British government has agreed to convert about 20 kilometres of country lane near Ashford, Kent, into a modern highway, but has otherwise said that people whose ambitions extend beyond the end of the tunnel must either create their own means of travel or wait until 1995, when there may be a fast railway link if only private entrepreneurs will build it (which is unlikely). It is Agincourt all over again. People from France will be exceedingly irritated, but nothing much in England will have changed. 